\title{
Serum immunoglobulin from Nellore cattle produced by in vitro fertilization and treated for umbilical diseases ${ }^{1}$
}

\author{
Celso Antonio Rodrigues ${ }^{2 *}$, Paulo Sergio P. Santos ${ }^{3}$, Francisco Leydson F. Feitosa ${ }^{3}$, \\ Sílvia Helena V. Perri ${ }^{4}$, Júlio Augusto N. Lisboa ${ }^{5}$, Piero Henrique M. Teodoro ${ }^{6}$, \\ Marcelo Augusto de Araújo ${ }^{7}$ and Mário Nelson Viana Filho ${ }^{8}$
}

\begin{abstract}
Rodrigues C.A., Santos P.S.P., Feitosa F.L.F., Perri S.H.V., Lisboa J.A.N., Teodoro P.H.M., Araújo M.A. \& Viana Filho M.N. 2018. Serum immunoglobulin from Nellore cattle produced by in vitro fertilization and treated for umbilical diseases. Pesquisa Veterinária Brasileira 38(2):256-261. Faculdade de Medicina Veterinária e Zootecnia, Departamento de Cirurgia e Anestesiologia Veterinária, Universidade Estadual Paulista, Rua Prof. Doutor Walter Mauricio Correa s/n, Cx. Postal 560, Botucatu, SP 18618-681, Brazil. E-mail: rodriguesca@fmvz.unesp.br

The aim of this study was to measure serum immunoglobulin concentrations of Nellore cattle produced by in vitro fertilization (IVF) with umbilical diseases and to evaluate surgical excision as a method of treatment. Sixteen cattle with ages ranging from 1 to 15 months, males and females, affected by umbilical diseases were enrolled in the study. Blood samples were collected for cell counts and the determination of immunoglobulin concentrations by electrophoresis and zinc sulphate turbidimetry (ZST). Four calves were presented with umbilical herniation, two with an umbilical herniation associated with a persistent urachus, two with an umbilical herniation with a persistent urachus and omphaloarteritis, three with an umbilical herniation and an urachal diverticulum, three with a persistent urachus, one with an urachal diverticulum, and one with omphalitis. The blood cell counts pre- and post-surgical revealed differences in cell volume and the number of leukocytes. The immunoglobulin values measured by electrophoresis values were below normal in most animals, whereas the ZST showed normal levels in most of them. Most of the calves affected by umbilical diseases and produced by IVF presented hypoglobulinaemia. Correlations between umbilical diseases, failure of passive transfer of immunity and IVF could not be demonstrated.

INDEX TERMS: Calves, clinics, persistent urachus, omphalitis, failure of passive transfer of immunity, in vitro fertilization.
\end{abstract}

RESUMO.- [Imunoglobulinas séricas de bovinos Nelore produzidos por fertilização in vitro e tratados para onfalopatias.] Os objetivos desse estudo foram mensurar as concentrações séricas das imunoglobulinas de bovinos

\footnotetext{
${ }^{1}$ Received on July 20, 2016.

Accepted for publication on March 7, 2017.

${ }^{2}$ Departamento de Cirurgia e Anestesiologia Veterinária, Faculdade de Medicina Veterinária e Zootecnia (FMVZ), Universidade Estadual Paulista (Unesp), Rua Prof. Doutor Walter Mauricio Correa s/n, Cx. Postal 560, Botucatu, SP 18618-681, Brasil. *Corresponding author: rodriguesca@fmvz.unesp.br

${ }^{3}$ Departamento de Clínica, Cirurgia e Reprodução Animal, Faculdade de Medicina Veterinária de Araçatuba (FMVA), Unesp, Rua Clóvis Pestana 793, Araçatuba, SP 16050-680, Brasil.

${ }^{4}$ Departamento de Apoio, Produção e Saúde Animal, FMVA-Unesp, Rua Clóvis Pestana 793, Araçatuba, SP 16050-680.
}

Nelore, produzidos por fertilização in vitro (FIV), acometidos por onfalopatias e avaliar a excisão cirúrgica como método de tratamento. Utilizou-se 16 animais, com idade variando de 1 a 15 meses, machos e fêmeas, acometidos por afecções

\footnotetext{
${ }^{5}$ Departamento de Clínicas Veterinárias, Centro de Ciências Agrárias (CCA), Universidade Estadual de Londrina (UEL), Campus Universitário, Cx. Postal 10.011, Londrina, PR 86057-970, Brasil.

${ }^{6}$ Mestrando, FMVZ-Unesp, Rua Prof. Doutor Walter Mauricio Correa s/n, Cx. Postal 560, Botucatu, SP 18618-681.

${ }^{7}$ Faculdade de Medicina Veterinária e Zootecnia, FAMEZ, Universidade Federal do Mato Grosso do Sul (UFMS), Av. Senador Felinto Müller 2443, Campo Grande, MS 79070-900, Brasil.

${ }^{8}$ Iniciação Científica, FMVA-Unesp, Rua Clóvis Pestana 793, Araçatuba, SP 16050-680.
} 
umbilicais. Amostras de sangue foram colhidas para realização de hemogramas e avaliação das imunoglobulinas, por meio de eletroforese e turbidimetria com sulfato de zinco. Foram observados quatro casos de hérnias umbilicais, dois de hérnia umbilical associadas à persistência de úraco, dois casos de hérnia umbilical com persistência de úraco e onfaloarterite, três de hérnia umbilical com divertículo de úraco, três casos de persistência de úraco, um de divertículo de úraco e um de onfalite. $\mathrm{O}$ hemograma revelou diferença significativa para os valores de Volume Globular e Leucócitos, nos momentos pré e pós-tratamento cirúrgico dos animais. A eletroforese evidenciou valores de imunoglobulina abaixo da normalidade na maioria dos animais, enquanto que a turbidimetria apresentou níveis normais na maioria dos bovinos, quando comparados com valores de referência. A maioria dos bovinos estudados, acometidos de onfalopatias e concebidos por FIV, apresentaram hipoglobulinemia. Os resultados obtidos não permitem afirmar que existe relação entre as onfalopatias, falha de transferência de imunidade passiva e FIV.

TERMOS DE INDEXAÇÃO: Bezerros, clínica, úraco patente, onfalite, falha de transferência de imunidade, fertilização in vitro.

\section{INTRODUCTION}

Infection of the umbilicus and its associated structures commonly occurs in newborn farm animals and seems to be particularly common in newborn calves (Vaala \& House 2006a, Seino et al. 2016). In addition to losses due to death, which occur in about $25 \%$ of cases, other damages may occur to contribute to decreased product development (Figueiredo 1999).

The failure of passive transfer of immunity (FPTI) is a major factor associated with the development of umbilical infections (Vaala \& House 2006b). The risk of systemic infection is negatively correlated with the amount and quality of the colostrum ingested during the first 12 hours of life (Steiner \& Lejeune 2009). FPTI can occur even in locations where good management practices have been adopted because, in some situations, animals born during the night are not adequately monitored after birth. Thus, a calf may not receive a suitable volume of colostrum by breast or receive it before or after the ideal time for the absorption of immunoglobulins (McGuire \& Adams 1982, Benesi 1993, White 1993).

According to Perino et al. (1993), there are several accurate methods to verify and quantify the FPTI by immunoglobulin in animals during their first days of life. For example, electrophoresis is one direct method for the quantification of immunoglobulin (Pfeiffer et al. 1977). However, this technique, although very specific, requires good technical skills and special equipment. In contrast, the ZST is an indirect method that is less specific than the direct method but is also rapid, low in cost and simple to perform (McEwan et al. 1970, White 1993).

According to Rodrigues et al. (2010) conservative therapies for umbilical diseases have a low success depending on the structure involved, whereas surgical treatment accompanied by broad-spectrum antimicrobial therapy is the treatment of choice for umbilical diseases because this technique enables excision of all infected structures.

Therefore, the objective of this study was to quantify serum immunoglobulin in Nellore calves conceived by IVF and affected by umbilical diseases and to evaluate surgical excision as the treatment method.

\section{MATERIALS AND METHODS}

The study was conducted using animals treated as part of the Large Animal Surgery service. Were used 16 animals of the Nellore purebred strain (Pure Origin), including males and females with ages ranging from 1 to 15 months that had been conceived through IVF and had a history of an irreducible swelling of firm consistency in the umbilical region.

During their hospitalization period, the animals were collectively housed in plots together with their mothers. They were provided a concentrated silage mixture and mineral water ad libitum and were also allowed to graze. Before the start of treatment, all animals were weighed, classified and tagged.

Prior to and 10 days after surgery, venous blood samples were collected in $4.5 \mathrm{~mL}$ tubes containing EDTA (K 3 EDTA, Labor Import, Osasco, SP, Brazil) via venipuncture of the jugular with an 18G needle (Precision Glide BD, Franklin Lakes, NJ, USA). Blood counts were performed using an automated blood cell counter (Animal Blood Counter, ABX Diagnostics, Sao Paulo, SP Brazil), and differential counts and cytology were performed according to the methods of Jain (1993).

Immediately prior to surgical treatment, venous blood samples were collected in $10 \mathrm{~mL}$ tubes lacking anticoagulant by jugular venipuncture, and the sera were subsequently obtained. The sera were frozen and stored for the quantification of immunoglobulin concentrations using both an indirect and a direct method.

The serum concentrations of albumin and of $\alpha 1, \alpha 2, \beta$ and $\gamma$ globulins were determined by electrophoresis (Kremers et al. 1967). Celmgels (CELM) and Tris buffer pH 9.5 (CELM) were used for electrophoresis, which was performed for 20 minutes using a 100 V current (IS-250 system, CELM, Barueri, SP, Brazil). After electrophoresis, the gel was stained with Amido Black and decolourised with $2 \%$ and $5 \%$ acetic acid (Labsynth Laboratory Products, Diadema, SP, Brazil). The proportion of each protein component was determined using the computer program system SDS-60 SE-250 (CELM), which was linked to a scanning densitometer.

The serum immunoglobulin $\mathrm{G}$ concentrations were estimated using the ZST technique and spectrophotometry, according to the method of Pfeiffer et al. (1977) with modifications. A $0.1 \mathrm{~mL}$ aliquot of serum was added to $6 \mathrm{~mL}$ of a solution containing $208 \mathrm{mg}$ of $\mathrm{ZnSO} 4 \bullet 7 \mathrm{H} 20$ per litre of distilled water. After one hour, the absorbance of the mixtures was measured spectrophotometrically (Cintra 5, GBC Scientific Equipment) at a wavelength of $620 \mathrm{~nm}$. Due to the instability of the solution, three readings were made, and the average was calculated. The amounts of serum IgG were estimated using a standard curve created with the following known concentrations of bovine IgG (Single Radial Immunodiffusion Kit; MARV, USA): zero (fetal bovine serum), 400, 800, 1,600 and 3,200mg/dL. The serum samples that yielded values exceeding the estimated 3,200 $\mathrm{mg} / \mathrm{dL}$ standard were diluted 1:1 with normal saline and re-processed.

For the surgical procedures, the animals were subjected to premedication (MPA) with xylazine $(0.07 \mathrm{mg} / \mathrm{kg}$ IM) and induction with ketamine (2mg/kg IV) combined with midazolam $(0.05 \mathrm{mg} / \mathrm{kg}, \mathrm{IV})$, followed by general anesthesia with isoflurane ( 0.8 to $1.5 \%$ IV) performed with the animals in the supine position. Ultrasound examinations were performed using an apparatus (Piemedical Easote Aquila Pro, Genova ITALY) set to 2.5-convex $5 \mathrm{MHz}$.

The extra-abdominal portion of a diseased umbilicus was dissected, and then the diseased intra-abdominal umbilical 
structures were identified and completely excised via an exploratory laparotomy.

Antimicrobial therapy consisted of the administration of $1 \mathrm{mg} / \mathrm{kg}$ of cefquinome intramuscularly at the time of MPA and then every 24 hours for 10 consecutive days. The animals also received $1.1 \mathrm{mg} / \mathrm{kg}$ of flunixin meglumine once a day for five consecutive days. The surgical wounds were dressed daily using topical antiseptic polyvinylpyrrolidone-iodine 10\% (Topic PVP-I).

The results for individual animals were compared at the end of the evaluations, and statistical significance was determined using either the paired t-test or the Wilcoxon test, depending on the variable being analyzed.

All procedures were performed using protocol CEEA 2008-002885, which was approved by the animal ethics committee of Univ Estadual Paulista, Unesp, and inspected by the animal welfare officer.

\section{RESULTS}

The clinical diagnosis and surgical and ultrasound examination of the animals in the current study revealed four cases of umbilical herniation, two cases of umbilical herniation with persistent urachus, two cases of umbilical herniation with persistent urachus and omphaloarteritis, three cases of umbilical herniation with an urachal diverticulum, three cases of persistent urachus, one case of an urachal diverticulum and one case of omphalitis (Table 1).
Our analysis identified significant differences between the pre-and post-surgical treatment values of packed cell volume (PCV) and leukocytes (LEUKO) in the blood (Table 2). The results for these variables were obtained using the values obtained from 15 animals because one post-surgery sample was lost.

Analysis of the differential counts showed that the neutrophil values were above the normal range in 12 animals pre-treatment and in seven animals post-treatment, whereas the lymphocyte values were above normal in 11 animals pre-treatment and in nine post-treatment. Both the pre- and post-treatment eosinophil counts were normal.

The total protein (TP) values were below normal for eight animals, normal for six animals and above normal for two animals. The albumin levels of eight calves were within the normal range, whereas seven had values below normal and one had value that was above normal. We measured the $\alpha, \beta$ and $\gamma$ globulin fractions separately and observed that $\alpha$ globulin values were normal for four animals, below normal for 11 animals and above normal for one animal. However the $\beta$ globulin values were normal range in 12 calves, three below and one above. The value for the $\gamma$ globulin fraction was normal in six animals and above normal in 10 animals, (Table 3). All these data studied were compared to the reference values obtained by Vettorato et al. (2009).

The turbidimetry results were satisfactory for 12 animals and below normal for the other four, as shown in Table 4.

Table 1. Distributions of the number and percentage of the 16 Nellore calves conceived by IVF, according to umbilical disease

\begin{tabular}{|c|c|c|c|}
\hline & Umbilical disease & Animals (N) & Animals $(\%)$ \\
\hline & Hernia & 4 & 25.00 \\
\hline & Hernia and patent urachus & 2 & 12.50 \\
\hline & $\begin{array}{l}\text { Hernia, patent urachus and } \\
\text { omphaloarteritis }\end{array}$ & 2 & 12.50 \\
\hline & Hernia and urachal diverticulum & 3 & 18.75 \\
\hline & Omphalitis & 1 & 6.25 \\
\hline & Urachal diverticulum & 1 & 6.25 \\
\hline & Patent urachus & 3 & 18.75 \\
\hline Total & & 16 & 100 \\
\hline
\end{tabular}

Table 2. Pre-treatment and post-treatment values for the blood count variables of 16 Nellorecalves expressed as the mean \pm standard deviation $(\overline{\mathrm{X}} \pm \mathrm{s})$ and the median $(\mathrm{Md})$

\begin{tabular}{|c|c|c|c|c|c|}
\hline \multirow{2}{*}{ Variable } & \multicolumn{2}{|c|}{ Pre-treatment } & \multicolumn{2}{|c|}{ Post-treatment } & \multirow{2}{*}{$\mathrm{P}$} \\
\hline & $\bar{X}_{ \pm s}$ & Md & $\bar{X} \pm s$ & Md & \\
\hline PCV (L/L) & $0.43 \pm 0.09$ & 0.44 & $0.39 \pm 0.08$ & 0.37 & $0.0343^{(1)}$ \\
\hline $\mathrm{TP}(\mathrm{g} / \mathrm{L})$ & $68.93 \pm 7.05$ & 70 & $66.20 \pm 9.03$ & 68 & $0.1457^{(1)}$ \\
\hline FIBR (g/L) & $4.27 \pm 1.53$ & 4 & $3.67 \pm 1.63$ & 4 & $0.2334^{(2)}$ \\
\hline NEUTR (x109/L) & $5.74 \pm 2.80$ & 5.15 & $4.34 \pm 2.34$ & 3.73 & $0.1354^{(2)}$ \\
\hline LINF (x109/L) & $9.79 \pm 3.66$ & 8.86 & $8.41 \pm 2.62$ & 8.02 & $0.1688^{(2)}$ \\
\hline MONO (x109/L) & $0.69 \pm 0.41$ & 0.58 & $0.62 \pm 0.28$ & 0.61 & $0.3894^{(2)}$ \\
\hline EOSI (x109/L) & $0.11 \pm 0.21$ & 0 & $0.24 \pm 0.25$ & 0.15 & $0.2676^{(2)}$ \\
\hline LEUKO (x109/L) & $16.33 \pm 4.54$ & 17.4 & $13.62 \pm 1.85$ & 14.2 & $0.0215^{(2)}$ \\
\hline $\mathrm{HB}(\mathrm{g} / \mathrm{L})$ & $129.73 \pm 24.77$ & 125 & $125.93 \pm 24.6$ & 118 & $0.3502^{(1)}$ \\
\hline HEM (x109/L) & $10.49 \pm 2.09$ & 9.96 & $10.14 \pm 1.83$ & 9.67 & $0.3325^{(1)}$ \\
\hline
\end{tabular}

Probability (P) determined with the paired t test (1) or the Wilcoxon test (2). 
Table 3. Individual mean values for each variable of the protein profile obtained by electrophoresis and reference values to TP, Albumin, $\alpha$ globulin, $\beta$ globulin and $\gamma$ globulin

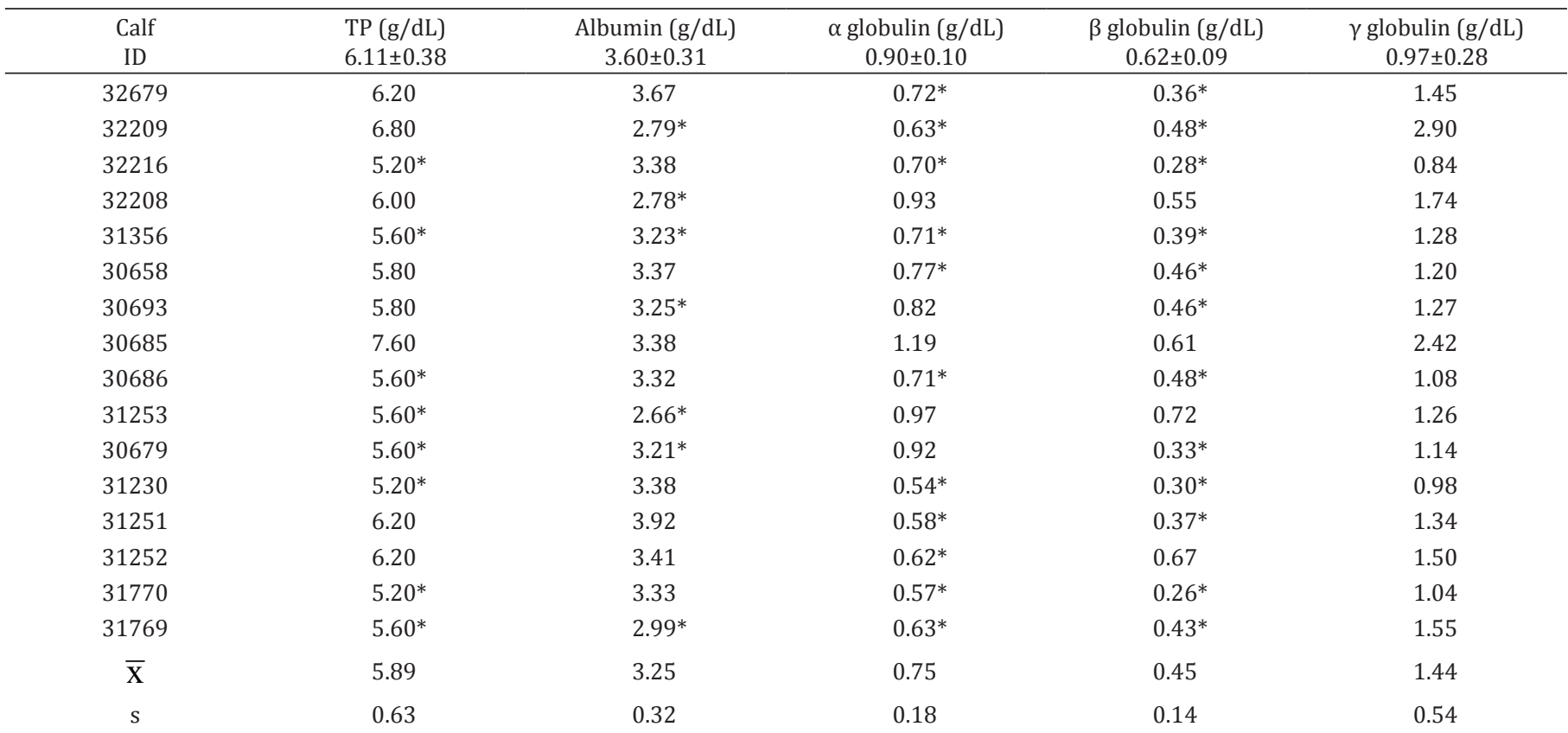

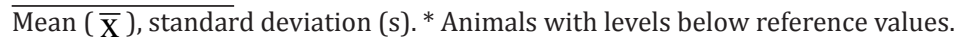

Table 4. The minimal and maximal reference values of immunoglobulin in $\mathrm{mg} / \mathrm{dL}(\mathrm{RV} \mathrm{mg} / \mathrm{dL}$ ) for the calves according to their age in days and the IgG values obtained using ZST

\begin{tabular}{ccc}
\hline Calf ID & $\begin{array}{c}\text { Age Group } \\
(\mathrm{RV} \mathrm{mg} / \mathrm{dL})\end{array}$ & $\begin{array}{c}\text { IgG } \\
(\mathrm{mg} / \mathrm{dL})\end{array}$ \\
\hline 32208 & 30 days & 2497.78 \\
32209 & $(879.66-2738.62)$ & 2160.08 \\
32216 & & 1827.45 \\
30693 & 90 days & 2283.34 \\
30686 & & $2151.64^{*}$ \\
30685 & & 2815.22 \\
30679 & 120 days & $2094.23^{*}$ \\
31253 & $(2248.40-3941.72)$ & 3019.53 \\
31769 & & 2955.37 \\
31770 & & 2281.65 \\
31356 & & 2423.49 \\
31251 & 180 days & 2320.49 \\
31252 & $(2212.53-4429.50)$ & 2558.57 \\
30658 & 365 days & 2833.79 \\
31230 & $(2739.53-4421.53)$ & $1949.02^{*}$ \\
32679 & & $1905.12^{*}$
\end{tabular}

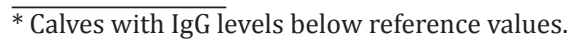

\section{DISCUSSION}

Umbilical diseases involving the urachus, including a persistent urachus and urachal diverticulum, either associated with or without other umbilical disorders, demonstrated the highest incidence in the animals studied. Surgical treatment was selected due to the low success rate for conservative therapies, as described by Figueiredo (1999) e Rodrigues et al. (2010).
Surgical treatment combined with broad-spectrum antimicrobial therapy effectively resolved the umbilical diseases and therefore enabled the complete excision of the infected structures, achieving a $100 \%$ success rate in the animals in this study. These data corroborate the results reported by Rodrigues et al. (2010) who also found that $100 \%$ of surgical treatments for umbilical diseases were successful.

Analysis of the pre-and post-surgical treatment blood cell counts results confirmed the relative improvement in all parameters evaluated and thereby demonstrated the efficacy of this treatment for umbilical diseases. Analysis of the pre-treatment blood counts showed that despite the clinically healthy appearance of the animals, they had abnormities in their leukocyte counts, as described in the results. Analysis of the pre-treatment white blood cell counts showed that most animals had neutrophil leukocytosis and lymphocytosis and that the number of leukocytes remained elevated post-treatment; however, in some animals, the number of neutrophils and lymphocytes decreased after treatment. Furthermore, it should be noted that the post-operative blood count was performed 10 days after surgery and that this period may be insufficient to assess reductions in the natural response to infection (Kaneko \& Cornelius 1989).

The protein profiles of the serum obtained by electrophoresis demonstrated that $\alpha, \beta$ and $\gamma$ globulin levels were mostly below normal, suggesting a correlation between hypoglobulinaemia and umbilical diseases. Other causes of this condition include inherited or acquired immunodeficiency (Thrall 2006), but these conditions could be ruled out in the animals studied because there were no infectious complications during their recovery from surgery. Furthermore, this could be proven by verifying the postoperative improvements in the blood count parameters evaluated. 
ZST often produces results that are similar to those obtained with electrophoresis. However, this was not observed in the current study because most animals $(n=13 / 16)$ had satisfactory levels of immunoglobulins within the normal range, indicating they had an adequate humoral immune response. The results of the turbidity step prior to electrophoresis can be attributed to the increased sensitivity of the latter technique resulting from its high specificity, as well as the fact that the ZST is an indirect qualitative method that quantifies only IgG. In contrast, determining the concentrations of serum immunoglobulin using electrophoresis is considered an accurate way to assess the functional status of the immune system because this method directly quantifies the $\alpha, \beta$ and $\gamma$ immunoglobulin fractions (Feitosa et al. 2001).

Another potential explanation for the low levels of globulins observed may be that the chronic infection conditions resulting from the presence of umbilical disease for up to 15 months caused the reduction of the immunoglobulin levels during this time (Kaneko \& Cornelius 1989). This explanation was supported by the elevation of lymphocytes levels, which were above normal in most of the animals studied ( $\mathrm{n}=11 / 16)$.

Albumin values generally do not change, even in cases of infection when globulin values are outside the normal range. In contrast, albumin levels are more influenced by changes in diet and in anemic processes associated with hypoproteinaemia (Kaneko \& Cornelius 1989) and this was observed in the animals studied because most animals $(n=10 / 16)$ had normal albumin values, despite demonstrating complete blood counts indicating an established infection.

Records from the farms where animals were born indicated that they had good management practices and used strict criteria for disinfection of the navel immediately after birth. However, there was no guarantee that these calves had ingested an appropriate volume of colostrum from the breast or that the colostrum had been ingested during the ideal period for immunoglobulin absorption because the immunoglobulin levels were measured only at treatment time. The hypoimunoglobulinaemia verified by electrophoresis in animals produced by IVF may not be the only explanation for the problem.

Various pathological conditions have been observed in animals produced by IVF and clones zebu, including biochemical changes, failure in the development of chorioallantoic membranes and blood vessels and morphological changes in the placentomes and fetal-maternal junctions (Bertolini et al. 2002, Meirelles et al. 2010, Birgel Junior et al. 2011, Pereira 2013). Farin et al. (2006) suggested that these changes could be potentially caused by defects in the print pattern and expression of genes regulating such mechanisms. Moore et al. (2007) pointed differences in insulin-like growth factor (IGF) gene expression during early placental attachment and rapid embryonic growth may directly or indirectly contribute to increased losses and abnormalities in IVF. Thus, umbilical diseases may have a multifactorial origin even in animals conceived by IVF, involving mainly defects in the passive transfer of immunity, printing and gene expression. However, this hypothesis requires additional scientific investigation.

\section{CONCLUSIONS}

Most Nellore calves conceived by IVF and suffering from umbilical diseases were found to be hypoglobulinaemic with elevated levels of $\alpha, \beta$ and $\gamma$ globulin fractions detected by electrophoresis, as compared to the normal reference values.
Although the results obtained show a relation between the occurrence of umbilical diseases, the FPTI and creation via IVF in Nellore calves, these findings were unable to conclude that the failure of passive transfer of immunity was responsible for the umbilical diseases.

Surgical excision combined with antimicrobial treatment was an effective treatment method for umbilical diseases.

\section{REFERENCES}

Benesi F.J. 1993. Síndrome asfixia neonatal nos bezerros: importância e avaliação crítica. Arqs Esc. Med. Vet. UFBA 16:38-48.

Bertolini M., Mason J.B., Beam S.W., Carneiro G.F., Sween M.L., Kominek D.J., Moyer A.L., Famula T.R., Sainz R.D. \& Anderson G.B. 2002. Morphology and morphometry of in vivo- and in vitro-produced bovine concepti from early pregnancy to term and association with high birth weights. Theriogenology 58(5):973-994. PMid:12212896. http://dx.doi.org/10.1016/S0093691X(02)00935-4.

Birgel Junior E.H., Meirelles F.V., Komninou E.R., Nunes M.T., Pogliani F.C., Fantinato Neto P., Yasuoka M.M., Pimentel J.R.V., Kubrusly F.S. \& Miglino M.A. 2011. Clinical disorders observed during the first 30 days of life of cloned Zebu calf. Acta Sci. Vet. 39(suppl. ):243-252.

Farin P.W., Piedrahita J.A. \& Farin C.E. 2006. Errors in development of fetuses and placentas from in vitro-produced bovine embryos. Theriogenology 65(1):178-191. PMid:16266745. http://dx.doi.org/10.1016/j. theriogenology.2005.09.022.

Feitosa F.L.F., Birgel E.H., Mirandola R.M.S. \& Perri S.H.V. 2001. Diagnóstico de falha de transferência de imunidade passiva em bezerros através da determinação de proteína total e de suas frações eletroforéticas, imunoglobulinas $\mathrm{G}$ e $\mathrm{M}$ e da atividade da gama glutamil transferase no soro sanguíneo. Cienc. Rural 31(2):251-255. http://dx.doi.org/10.1590/ S0103-84782001000200010.

Figueirêdo L.J.C. 1999. Onfalopatias de bezerros. Editora da Universidade Federal da Bahia, Salvador. 94p.

Jain N.C. 1993. Essentials of Veterinary Hematology. Lea and Febiger, Philadelphia. 417p.

Kaneko J.J. \& Cornelius C.E. 1989. Clinical Biochemistry of Domestic Animals. Academic Press, New York. 932p

Kremers B., Briere R. \& Batsakis J.G. 1967. Reflectance densitometry of cellulose acetate protein eletrophoresis. Am. J. Med. Technol. 33(1):2834. PMid:6037911.

McEwan A.D., Fisher E.W., Selman I.E. \& Penhale W.J. 1970. A turbidity test for the estimation of immune globulin levels in neonatal calf serum. Clin. Chim. Acta 27(1):155-163. PMid:4189647. http://dx.doi.org/10.1016/00098981(70)90390-6.

McGuire T.C. \& Adams D.S. 1982. Failure of colostral immunoglobulin transfer to calves: prevalence and diagnosis. Cont. Educ. Article 4(1):35-40.

Meirelles F.V., Birgel Junior E.H., Perecin F., Bertolini M., Traldi A.S., Pimentel J.R., Komninou E.R., Sangalli J.R., Neto P.F., Nunes M.T., Pogliani F.C., Meirelles F.D., Kubrusly F.S., Vannucchi C.I. \& Silva L.C. 2010. Delivery of cloned offspring: experience in Zebu cattle (Bos indicus). Reprod. Fertil. Dev. 22(1):88-97. PMid:20003849. http://dx.doi.org/10.1071/RD09229.

Moore K., Kramer J.M., Rodriguez-Sallaberry C.J., Yelich J.V. \& Drost M. 2007. Insulin-like growth factor (IGF) family genes aberrantly expressed in bovine conceptuses produced in vitro or by nuclear transfer. Theriogenology 68(5):717-727. PMid:17628655. http://dx.doi.org/10.1016/j. theriogenology.2007.06.001.

Pereira L.S. 2013. Aspectos anatomopatológicos de clones bovinos abortados e neonatos. Dissertação de Mestrado, Faculdade de Agronomia e Medicina Veterinária, Universidade de Brasília, Brasília, DF. 90p. 
Perino L.J., Sutherland R.J. \& Woolen N.E. 1993. Determination of passive immunity in calves. Agricult. Res. Serv. 71(5):176-179.

Pfeiffer N.E., McGuire T.C., Bendel R.B. \& Weikel J.M. 1977. Quantitation of bovine immunoglobulins: comparison of single radial immunodiffusion, zinc sulfate turbidity, serum electrophoresis, and refractometer methods. Am. J. Vet. Res. 38(5):693-698. PMid:406822.

Rodrigues C.A., Santos P.S.P., Perri S.H.V., Teodoro P.H.M., Anhesini C.R., Araújo M.A. \& Viana Filho M.N. 2010. Correlação entre os métodos de concepção, ocorrência e formas de tratamento das onfalopatias em bovinos: estudo retrospectivo. Pesq. Vet. Bras. 30(8):618-622. http://dx.doi.org/10.1590/ S0100-736X2010000800002.

Seino C.H., Bombardelli J.A., Reis G.A., Santos R.B., Shecaira C.L., Azedo M.R. \& Benesi F.J. 2016. Avaliação ultrassonográfica de componentes umbilicais inflamados em bezerros da raça Holandesa com até 30 dias de vida. Pesq. Vet. Bras. 36(6):492-502. http://dx.doi.org/10.1590/S0100736X2016000600006.
Steiner A. \& Lejeune B. 2009. Ultrasonographic assessment of umbilical disorders. Vet, Clin. N. Am. Food Anim. Pract. 25(3):781-794. http://dx.doi. org/10.1016/j.cvfa.2009.07.012.

Thrall M.A. 2006. Hematologia e Bioquímica Clínica Veterinária. Roca, São Paulo. 582p.

Vaala W.E. \& House H.K. 2006a. Úraco patente, onfalite e outras anormalidades umbilicais, p.368-370. In: Smith B.P. (Ed.), Medicina Interna de Grandes Animais. $3^{\underline{a}}$ ed. Manole, Barueri, SP.

Vaala W.E. \& House H.K. 2006b. Infecção neonatal, p.303-318. In: Smith B.P. (Ed.), Medicina Interna de Grandes Animais. $3^{\mathrm{a}}$ ed. Manole, Barueri, SP.

Vettorato E.D., Flaiban K.K.M.C., Costa M.C., Balarin M.R.S., Vidotto O. \& Lisbôa J.A.N. 2009. Concentrações séricas de gamaglobulina e IgG em bezerros das raças nelore e holandesa do nascimento aos seis meses de vida. Ciênc. Anim. Bras. (suppl. 1):238-243.

White D.G. 1993. Colostral suplementation in ruminants. Compend. Cont. Educ. Vet. Pract. 15(3):335-342. 